restriction was in pursuance of the provisions of a charitable instrument. Catholic Care therefore sought and was refused the Charity Commission's consent to amend its Memorandum of Association so as to bring it within the exemption regime.

In its second appeal to the Upper Tribunal, Catholic Care accepted that religious conviction alone could not in law justify the denial of its adoption services to same-sex couples but argued that its proposal was proportionate to achieving a legitimate aim of continuing its services because same-sex couples would be able to use other voluntary adoption agencies and local authorities. Moreover, if it could not discriminate it would lose its voluntary income; and if it were to close, the overall provision of adoption services and the number of children placed with adoptive families would be reduced. Sales J rejected Catholic Care's latest appeal. He agreed with the First-Tier Tribunal that it had failed to demonstrate sufficiently weighty reasons to justify the proposed discrimination. The fact that same-sex couples could seek access to adoption services elsewhere would not stop them from feeling discriminated against or mitigate the harm done to the general promotion of equal treatment for heterosexuals and homosexuals. [Frank Cranmer]

doi:10.1017/So956618X13000100

\title{
Catholic Child Welfare Society and others v Various Claimants and The Institute of the Brothers of the Christian Schools and others
}

Supreme Court: Lord Phillips, Baroness Hale, Lords Kerr, Wilson and Carnwath, 21 November 2012

[2012] UKSC 56

School - sexual abuse - vicarious liability - religious order

The members of the Institute are lay religious. The Institute provided the teachers for St William's School, Market Weighton, which closed in 1994. The school had been managed by the Middlesbrough Diocesan Rescue Society until 1982 and thereafter by the Catholic Child Welfare Society (Diocese of Middlesbrough). The previous headmaster, Brother James, had been convicted of a series of sexual offences against boys; and 170 former pupils brought claims against both the managers of the school from 1973 (the Middlesbrough Defendants) and the Institute itself, arguing vicarious liability for alleged acts of sexual and physical abuse committed between 1952 and 1992. The brothers who taught at the school were not contracted to the Institute but to the Middlesbrough Defendants, under secular contracts of employment. On a preliminary issue the High Court held - and the Court 
of Appeal confirmed - that the Institute was not vicariously liable for any abuse. The Middlesbrough Defendants appealed, arguing that the Institute should share vicarious liability.

The Supreme Court allowed the appeal. Delivering the judgment of the Court, Lord Phillips concluded that the necessary relationship between the brothers and the Institute and the close connection between that relationship and the abuse committed at the school had been made out; that the business and mission of the Institute to give a Christian education to boys was the common business and mission of every brother who was a member of it; and that there was a very close connection between the relationship of the brothers with the Institute and the employment of the brothers as teachers in the school. In short, the brother-teachers' employment at the school was sufficiently closely connected with the sexual abuse that they must be assumed to have committed and it was therefore fair, just and reasonable, by reason of the satisfaction of the relevant criteria, that the Institute should share vicarious liability with the Middlesbrough Defendants. [Frank Cranmer]

doi:10.1017/So956618X13000112

\section{Re St Cyriac, Lacock}

Bristol Consistory Court: Gau Ch, 4 December 2012 Plate - sale - redundancy

The petitioners sought a faculty for the sale of the fifteenth-century Lacock Cup, which had been given to the church in the seventeenth century for use as a chalice. From 1962 it was loaned to the British Museum. Until 1981 the cup had occasionally been returned to the church for liturgical use. In 2006 it was realised that there was no faculty for the loan. A confirmatory faculty was granted for ten years on condition that the cup be insured for at least $\mathcal{E}_{1.8}$ million. The current petition arose from the British Museum's offer to buy the cup for $£^{1.3}$ million. The parochial church council (PCC) submitted that the insurance and security required to allow safe return of the cup to Lacock, even temporarily, was unaffordable, rendering the cup redundant. Additionally, they argued that substantial sums were needed to repair the church and that insuring a valuable asset with no practical use was not consistent with the PCC's duties. The petition was opposed by a parishioner, claiming the support of signatories to a pro forma petition. He argued that the cup should be returned to Lacock for local display, challenging evidence that insurance and security were prohibitive. The chancellor refused to admit in evidence the pro forma petitions and leaflets submitted by the party opponent as they contained 